\section{What are the risks?}

What would be the consequences of the constitutional separation of Québec for science in Quebéc itself and in Canada more generally? Everything would depend on the manner of the separation, on the fine print of an eventual agreement between Québec and the eleven other provinces that constitute Canada now. One of the more curious of present circumstances is that the scientific community seems to have given little thought to what separation would entail in practice.

That is understandable. Whatever their mother tongue, researchers appear to be either against separation or lukewarm about it. Moreover, although the political process could be quick, actual separation must be delayed. A decisive result in a referendum next year could set constitutional talks in train before the end of 1995 , but nobody expects that process to be completed quickly.

Meanwhile, there is a sense in which to discuss in detail what separation entails is to tempt Providence, as if talking about separation will make it happen. But the usual working hypothesis is that, in the conduct and funding of research, separation would bring no change. People suppose that the working relationships they have already established with groups elsewhere in Canada, or further afield, would survive. Some even suppose that the federal research councils would survive separation intact.

What would inevitably change is the emphasis given to the French language. The complaint in the $1960 \mathrm{~s}$ was that Québec research languished because applications for funds were not properly understood. Even now that federal Canada is biligual, traces of this sense of injectice persist. Some in Quebec complain that, when applications are now sent to supposedly bilingual referees elswhere in Canada, they are often imperfectly understood and, as a consquence, are inadequately assessed. In the nature of things, there is no way of distinguishing between that state of affairs and the more general indignation that the doings of referees stimulate.

For a separate Québec, there is no reason to suppose that the mechanics of the refereeing process would be a greater handicap than it is now. The international research community, in Canada and elsewhere, would presumably be as ready then as now to read colleagues' manuscripts and grant applications. Moreover, the crucial quality of a referee is that he or she should be able to understand the science. Merely understanding the languages usually a secondary consideration.

A more serious consideration is that a separate Québec might be tempted (or even forced by its constitution) to narrow the circle of those whose opinions help in making decisions. Lively though Québec's research community may now be, it is far from self-sufficient. Even Canada's federal research councils include scientists from elsewhere on their advisory committees (some of whom are from France and Belgium). A separate Québec would, in its own interests, even more vigorously follow that course.

A much more serious question is whether a separate Québec would run its own mechanism for the funding of research. On the face of things, it is improbable that a provincial government that makes research a central pillar of its policy would continue to contribute funds to central research councils so that they could reallocate them among research groups throughout Canada. In other words, Québec's present arrangements for supplementing the support offered by the federal research councils seem destined to grow into a separate Québec's machinery for research support.

Researchers have good cause to fear that such a development would destroy the plurality they enjoy at present. A more substantial difficulty is that the academic function of the Fonds which at present support research in the natural sciences, health research and technology (see previous page) as well as in the social sciences and the humanities, is to enable selected departments or research groups to compete more effectively for federal research funds. The awkward question is whether, without conflict of interest, it would be possible for unified research councils both to single out candidate recipients of research grants and then to award those grants objectively.

These difficulties, about peer-review and funding mechanisms, but especially the second, would apply with almost equal force to Canada without Québec. Although some researchers elsewhere would welcome the illusion that separation would rid them of the present need to be bilingual, the geographical gulf between Ontario and British Columbia would then seem even greater than now.

Some in Québec raise a further difficulty, saying that the provincial government's rhetoric about its commitment to research has not been fully reflected in the annual budgets of Québec's independent research Fonds. All governments are faced with the difficulty of knowing how much research support is enough, but statistics support the complaint that the Fonds could usefully spend more.

Although Québec's direct support of academic research grew fourfold in 1980s (to about $\mathrm{C} \$ 120$ million a year), both the value and the proportion of federal re search grants awarded to researchers at
Québec universities and institutions are still increasing. In other words, it seems that the Fonds have not yet exhausted the supply of university departments and groups able to compete successfully with others elsewhere in Canada. Even if separation never happens, the provincial government might usefully be challenged on that score.

But the most serious danger of separation would be that with which Québec's university system would be faced. Much of it is relatively new, with the consequence that there has not yet been time for some institutions to strike a balance between teaching and research, McGill University, with 30,000 students, has 1,500 faculty members and was responsible in 1991 for 38 per cent of Québec's output of scientific publications. The Université de Québec à Montréal, by contast, has 40,000 students, 1,000 faculty members and produced 7.6 per cent of Québec's research publications in the same year.

The purpose of this comparison is nothing other than to suggest that, for reasons to do with the balance between teaching and research, not all components of Québec's university system are equally active in research. But that, in turn, implies that the effective mass of Québec's academic research enterprise is less than simple head-count would suggest. Yet even by that yardstick, it is small - too small in many fields to be a critical mass. Researchers seem ready to acknowledge that; it is not clear whether politicians bent on separation agree.

These are the moderate alarms occasioned by the propsect of separation. There are, of course, other less moderate alarms, not least that a separate Québec would be a chauvinistic Québec, culturally and politically more distant from the remainder of Canada than from, say, the United States or even France. No doubt the remainder of Canada would abreact to such a development, with disastrous consequences for general civility.

That is one reason why the general detachment of the research community from the issue of whether separation becomes a reality is difficult to understand. For Québec, the project has the attractiveness of an adventure without obvious or immediate risk. The foreseable dangers are more distant, while the chance of blundering into crisis is discounted.

For the rest of Canada, the outlook is very much the same: the hazards of separation would depend on how separate a separate Qúbec would be. But Canada as a whole seems not yet to have appreciated how the clamour for separation, like the recent wave of immigration from South East Asia, has drawn attention to the cultural diversity of a vast country better known for being empty of people, even of interest. Is that not worth strug gling to keep?

John Maddox 